\title{
PCR Analysis of Immunoglobulin Heavy Chain (IgH) and TcR- $\gamma$ Chain Gene Rearrangements in the Diagnosis of Lymphoproliferative Disorders: Results of a Study of 525 Cases
}

Catherine Thériault, M.D., Sandrine Galoin, Ph.D., Severine Valmary, M.D., Janick Selves, M.D., Laurence Lamant, M.D., Daniel Roda, Françoise Rigal-Huguet, M.D., Pierre Brousset, M.D., Ph.D., Georges Delsol, M.D., Talal Al Saati, M.D., Ph.D.

Department of Pathology, UPCM/CNRS UPR 2163 (CT, SG, SV, JS, LL, DR, PB, GD, TA); and Department of Hematology (FRH), CHU-Purpan, Toulouse, France.

This report summarizes a cumulative 4-year experience in polymerase chain reaction (PCR) analysis of immunoglobin heavy chain (IgH) and TcR- $\gamma$ chain gene rearrangements in 525 cases of lymphoproliferative disorders. Because the sensitivity of the PCR methodology was found to be tissue dependent, in the study of the presence of clonal cell population in tissues containing a small number of polyclonal lymphocytes, such as skin and gastrointestinal biopsy specimens, we used the multiplePCR run approach. In this latter methodology, we repeat the PCR reaction from the same sample at least three times to confirm the reproducibility of the results. In the study of 273 cases of B- or T-cell lymphomas with characteristic immunomorphological and clinical features, a clonal IgH or TcR- $\gamma$ chain gene rearrangement was detected in approximately $80 \%$ of cases. A clonal rearrangement involving both IgH and TcR- $\gamma$ chain genes was found in $10 \%$ of cases of both B-cell and T-cell lymphomas. The study of 167 cases of nonneoplastic lymphoid tissue samples showed the presence of clonally rearranged cell populations for IgH or TcR- $\gamma$ genes in 3 and $9 \%$ of cases, respectively. We also applied PCR for the study of 85 cases of lymphoproliferations with no definite diagnosis (i.e., benign versus malignant) after immunomorphological analysis. In 65 cases ( $76 \%$ ), the correlation of immunomorphological features with the presence (48 cases) or the absence (17 cases) of clonal lym-

Copyright (C) 2000 by The United States and Canadian Academy of Pathology, Inc.

VOL. 13, NO. 12, P. 1269, 2000 Printed in the U.S.A.

Date of acceptance:

Address reprint requests to: Dr. Talal Al Saati, Unité de Physiologie Cellulaire et Moléculaire, PCM/CNRS UPR 2163, CHU Purpan, Avenue de Grande Bretagne, 31300 Toulouse, France; e-mail: alsaati@immgen. cnrs.fr; fax: 33561499036.

This work was supported by La ligue Contre le Cancer, Comité 31 and Délégation à la Recherche Clinique et PHRC 1998. phoid cell populations led to a definite diagnosis. In almost all these cases, the final diagnosis was found to be in agreement with the clinical course. In the 20 remaining cases $(\mathbf{2 4 \%})$, no definite diagnosis could be made. We also assessed the value of PCR in detecting bcl-2/J $\mathrm{J}_{\mathrm{H}}$ gene rearrangement as an additional clonal marker in the diagnosis of follicular lymphoma. Bcl-2/J $\mathrm{J}_{\mathrm{H}}$ rearrangement and/or IgH gene rearrangement was found in approximately $85 \%(71 / 85)$ of follicular lymphoma cases studied.

KEY WORDS: bcl-2/J $\mathrm{J}_{\mathrm{H}}$, Clonality, IgH, Lymphoid proliferations, Multiple-PCR run approach, PCR, TcR- $\gamma$.

Mod Pathol 2000;13(12):1269-1279

Immunoglobulin (Ig) and T-cell receptor (TcR) gene rearrangement studies have been successfully applied to investigate the clonality and cell lineage of various lymphoid malignancies (1). Consensus oligonucleotide primers directed to the Framework 3 (FRIII) and, to a lesser extent, Framework 2 (FRII) and Framework 1 (FRI) regions of the IgH genes have been used to detect B-cell clonality (2-5). The detection rate in previous studies varies from 50 to nearly $100 \%$ (6-8). However, recent studies have shown that the detection rate of IgH rearrangement was closely related to the cell origin of malignant lymphomas (1). Thus, tumors derived from naive lymphocytes, also designated pre-germinal center (pre-GC) naive $\mathrm{B}$ cells, express unmutated $\mathrm{V}_{\mathrm{H}^{-}}$ region genes and show a high detection rate of clonal IgH gene rearrangement by polymerase chain reaction (PCR). In this category are precursor B-lymphoblastic leukemia/lymphoma, mantle cell lymphoma, and a subset of chronic lymphocytic leukemia $(9,10)$. The other group of tumors derived from memory B cell, generated in the GC and characterized by cells bearing somatically hypermu- 
tated $\mathrm{V}_{\mathrm{H}}$-region genes (GC and post-GC memory B cells), give a lower rate of clonality by PCR methodology. In the latter group are the majority of non-Hodgkin's B-cell lymphoma subtypes such as lymphoplasmacytic, mucosa-associated lymphoid tissue (MALT) type, follicle-center lymphomas, hairy cell leukemia, diffuse large-cell lymphomas, Burkitt's lymphomas, multiple myeloma, and some chronic lymphocytic leukemias $(9,10)$. In these latter cases, the mutations at binding sites of the primers account for the lower amplification rate of $\mathrm{IgH}$ gene rearrangements (4). Therefore, the use of more than one appropriate set of primers in these lymphomas has been shown to yield higher detection rates varying from 80 to $90 \%$ (11-13).

To evaluate T-cell receptor gene rearrangements, $\mathrm{T}$-cell receptor- $\gamma$ chain (TcR- $\gamma$ ) gene rearrangement is frequently investigated because it occurs at an early stage of T-cell development and can be found in almost all T-lymphoid neoplasms $(14,15)$. The detection rate of clonal TcR- $\gamma$ gene rearrangement in non-Hodgkin's T-cell lymphoma, using different sets of primers specific for the $\mathrm{V} \gamma$ and $\mathrm{J} \gamma$ gene regions, varies from 60 to $100 \%$ (16-19).

This report summarizes our cumulative 4-year experience using PCR for detecting IgH and TcR- $\gamma$ as well as bcl- $2 / \mathrm{J}_{\mathrm{H}}$ gene rearrangements in lymphoproliferative disorders. We also tried to define the optimal sets of primers for detecting clonality in a broad morphologic spectrum of B- and T-cell lymphomas. The detection rate was also correlated with the cell origin of malignant lymphoma (i.e., pre-GC or GC and post-GC) subtypes. In addition, to assess the diagnostic value of PCR in difficult cases (i.e., benign versus malignant), we investigated 85 cases of lymphoproliferations with no definite diagnosis after immunomorphological analysis.

\section{MATERIALS AND METHODS}

\section{Patients and Specimens Studied}

The material used in the present study was collected in the tissue bank of the Department of Pathology at Purpan hospital in Toulouse, France from February 1987 to December 1997. We started the use of the PCR methodology for a diagnostic purpose in our laboratory at the beginning of 1994, and the results included in this report are based on a cumulative 4-year experience of PCR; that is, to the end of 1997. The specimens available in our tissue bank before 1994 were used to increase the number of well-characterized neoplastic and nonneoplastic lesions and to perform clinicopathologic correlations. Seven hundred four samples from 525 patients with various lymphoid disorders were included (sample numbers were as follows: lymph nodes, 272; tonsils, 22; spleens, 14; bone marrows,
146; skin biopsies, 141; gastrointestinal tract samples, 50; and various nonlymphoid tissue specimens, 59).

The diagnosis of lymphoma subtypes was based on immunomorphologic criteria according to the Revised European-American Lymphoma classification (20; Table 1). These patients included 290 men and 235 women and were aged from 1 to 93 years, with a majority of adult patients $(n=448[85 \%])$.

On the basis of their immunomorphologic features, these cases were classified as non-Hodgkin's lymphomas $(n=273)$ of B-cell $(n=183)$ or T-cell phenotype ( $n=90$; Table $1 ; 21,22)$. We also applied PCR to 85 cases of lymphoproliferations with no definite diagnosis (benign versus malignant) after immunomorphological analysis. For the latter cases, clinical findings anad follow-up were correlated with immunohistologic features and PCR findings. Beside malignant lymphoproliferative disorders, 167 cases of various nonneoplastic lymphoid disorders were also investigated. Clonal non-

\section{TABLE 1. Results of IgH and TcR- $\gamma$ Gene} Rearrangements in 273 Cases of Non-Hodgkin's Lymphomas of B-Cell $(n=183)$ and T-Cell $(n=90)$ Phenotype Classified According to the REAL Classification

\begin{tabular}{|c|c|c|}
\hline Type & IgH $+/$ Tested & TcR- $\gamma+/$ Tested $^{*}$ \\
\hline \multicolumn{3}{|l|}{ B-cell lymphoma: } \\
\hline \multicolumn{3}{|l|}{ Pre-GC B-cell: } \\
\hline $\begin{array}{l}\text { Precursor B-lymphoblastic } \\
\text { leukemia }\end{array}$ & $2+/ 2$ & $0+/ 2$ \\
\hline $\begin{array}{l}\text { Chronic lymphocytic } \\
\text { leukemia** }\end{array}$ & $11+/ 12$ & $0+/ 12$ \\
\hline Mantle cell & $12+/ 12$ & $0+/ 12$ \\
\hline Total & $25+/ 26(96 \%)$ & $0+/ 24\left(\begin{array}{ll}0 & \%\end{array}\right)$ \\
\hline \multicolumn{3}{|l|}{ GC and post-GC B-cell: } \\
\hline Lymphoplasmacytoid & $3+/ 4$ & $1+/ 4$ \\
\hline Follicle center & $65+/ 85$ & $8+/ 85$ \\
\hline MALT type & $11+/ 14$ & $2+/ 14$ \\
\hline Myeloma & $0+/ 1$ & $0+/ 1$ \\
\hline Diffuse large cell & $30+/ 38$ & $5+/ 38$ \\
\hline Burkitt & $0+/ 1$ & $0+/ 1$ \\
\hline Total & $109+/ 143(76 \%)$ & $16+/ 143(11 \%)$ \\
\hline Unclassified: & $10+/ 14$ & $2+/ 14$ \\
\hline Total & $144+/ 183(79 \%)$ & $18+/ 183(10 \%)$ \\
\hline Type & TcR- $\gamma+/$ Tested & IgH+/Tested ${ }^{* * *}$ \\
\hline \multicolumn{3}{|l|}{ T-cell lymphoma: } \\
\hline Chronic lymphocytic leukemia & $2+/ 3$ & $0+/ 3$ \\
\hline $\begin{array}{l}\text { Mycosis Fungoide/Sezary } \\
\text { syndrome }\end{array}$ & $12+/ 12$ & $1+/ 12$ \\
\hline Peripheral T-cell & $10+/ 10$ & $1+/ 10$ \\
\hline Angioimmunoblastic T-cell & $10+/ 12$ & $3+/ 12$ \\
\hline Angiocentric T-cell & $1+/ 1$ & $0+/ 1$ \\
\hline Lymphoblastic & $0+/ 2$ & $0+/ 2$ \\
\hline Unclassified & $20+/ 21$ & $2+/ 21$ \\
\hline Anaplastic large cell & $19+/ 29$ & $3+/ 29$ \\
\hline Total & $74+/ 90(82 \%)$ & $10+/ 90(11 \%)$ \\
\hline
\end{tabular}

${ }^{*} \mathrm{TcR}-\gamma$ gene rearrangement is associated with IgH gene rearrangement in these cases.

** Recent studies have demonstrated that there are 2 subtypes of CLL: one derives from pre-GC B-cell and the other from post-GC memory B-cells $(9,10)$.

*** IgH gene rearrangement is associated with $\mathrm{TcR}-\gamma$ gene rearrangement in these cases. 
Hodgkin's B- (OCI LY8; 23) or T-cell lymphoma (CEM and HSB-2; ATCC CCL 119 and ATCC CCL 120.1) cell lines were used as positive controls for IgH and TcR- $\gamma$ gene rearrangements, respectively (22). In addition, OCI LY8 positive for the major breakpoint region (MBR) of the $t(14 ; 18)(q 32 ; q 21)$ translocation and a follicular lymphoma (FL) positive for the translocation involving the minor cluster region (mcr) were used as positive controls for bcl $-2 / \mathrm{J}_{\mathrm{H}}$ rearrangements.

Tissue specimens were received fresh in our laboratory. For every sample, except for bone marrow biopsies, one half was snap-frozen in liquid nitrogen and stored at $-80^{\circ} \mathrm{C}$ for immunostaining on cryostat sections and DNA extraction, and the other half was fixed in Duboscq-Brasil (ethanol-based Bouin's fluid) for routine morphological diagnosis and immunostaining on paraffin-embedded tissue sections. For bone marrow biopsy samples, the first half was fixed in acetone and embedded in paraffin using the ModAMeX method described elsewhere, which was developed for simultaneous study of cell morphology and fixation-sensitive leukocyte differentiation antigens (21). The ModAMeX method was also used for DNA extraction.

\section{DNA Isolation and PCR Analysis of Tissue Samples}

\section{DNA extraction}

Total cellular DNA from tissue biopsy samples was extracted from 10 frozen or ModAMeX sections (each $10 \mu \mathrm{m}$ thick) using standard technique (22). For small biopsy specimens, DNA was extracted from tissue sections using proteinase $\mathrm{K}$ digestion in buffer $(100 \mu \mathrm{L}$ Tris $50 \mathrm{~mm}$, EDTA $10 \mathrm{~mm}, \mathrm{NaCl} 100$ mM; $\mathrm{pH} 8$; 24). Amplification of a fragment of the housekeeping gene c-raf-1 (258-bp fragment; 25$)$ or $\beta$-actin (606-bp fragment; 26) was used as a positive control for successful amplification of the extracted DNA (Table 2). In addition, all standard precautions were taken to guard against cross-contamination of amplified DNA (27). In each experiment, a polyclonal DNA (reactive lymphoid tissues) and negative (sterile water [blank]) controls were systematically included.

\section{Primer Design}

Analysis of IgH gene rearrangements was performed by seminested PCR (sn-PCR) according to the method of Trainor et al. (2) and Ramasamy et al. (3), using FRII- $\mathrm{V}_{\mathrm{H}}$ and FRIII- $\mathrm{V}_{\mathrm{H}}$-specific primer amplifications (Table 2). In addition, the consensus FR1c primer described by Aubin et al. (5), directed against a highly conserved region in the FRI region shared by the $7 \mathrm{~V}_{\mathrm{H}}$ families, was employed for the FRI- $_{\mathrm{H}}$ amplification using the same methodology described for the two other $\mathrm{V}_{\mathrm{H}}$ framework-specific primers.

The demonstration of TcR- $\gamma$ gene rearrangements was performed by using two rounds of multiplex PCR with a set of seven primers $(22,28$; Table $2)$. These primers were used in two mixes: Mix 1 contained $\mathrm{V} \gamma \mathrm{I}$ cons in conjunction with $\mathrm{J} \gamma 2 \mathrm{~S} 2$, JP and JP1/2 primers, and Mix 2 contained $\mathrm{V} \gamma$ 9.2, $\mathrm{V} \gamma$ 10 , and $\mathrm{V} \gamma 11$ in association with $\mathrm{J} \gamma 2 \mathrm{~S} 2$, JP and JP1/2 primers. For each sample, two PCR amplifications were performed, using first Mix 1 and then

TABLE 2. Sequences of Primers and Probes

$\begin{array}{ll}\text { House keeping genes: } & \\ \text { 1-Actin } & : 5^{\prime} \text {-TCA TGT TTG AGA CCT TCA A-3' } \\ \text { 2-Actin } & : 5^{\prime} \text {-GTC TTT GCG GAT GTC CAC G-3' } \\ \text { Raf } 8+ & : 5^{\prime} \text {-GAT GCA ATT CGA AGT CAC AGC G-3' } \\ \text { Raf 9- } & : 5^{\prime} \text {-TTT TCT CCT GGG TCC CAG ATA-3' } \\ \text { t(14;18) translocation: } & \\ \text { MBR3+ } & : 5^{\prime} \text {-TTT GAC CTT TAG AGA GTT GCT TTA CG-3' } \\ \text { MC8 } & : 5^{\prime} \text {-GAC TCC TTT ACG TGC TGG TAC C-3' } \\ \text { JH- } & : 5^{\prime} \text {-ACC TGA GGA GAC GGT GAC C-3' } \\ \text { MBR-P+ } & : 5^{\prime} \text {-GCC TGT TTC AAC ACA GAC CCA C -3' } \\ \text { MC12-F+ } & : 5^{\prime} \text {-GAT GGC TTT GCT GAG AGG TAT TG-3' } \\ \text { Ig heavy chain (IgH) } & \\ \text { genes: } & \\ \text { FR1c } & \\ \text { FR2a } & : 5^{\prime} \text {-AGG TGC AGC TG(G/C) (A/T)G(G/C) AGT C(G/A/T)G G-3' } \\ \text { FR3a } & : 5^{\prime} \text {-TGG (A/G)TC CG(C/A) CAG (G/C)C(T/C) (T/C)CN GG-3' } \\ \text { LJH } & : 5^{\prime} \text {-ACA CGG C(C/T)(G/C) TGT ATT ACT GT-3' } \\ \text { VLJH } & : 5^{\prime} \text {-TGA GGA GAC GGT GAC C-3' } \\ \text { TcR- } \gamma \text { genes: } & : 5^{\prime} \text {-GTG ACC AGG GTN CCT TGG CCC CAG-3' } \\ \text { V } \gamma \text { I cons } & \\ \text { V } \gamma 9.2 & : 5^{\prime} \text {-CTG GTA CCT ACA CCA GGA GGG GAA-3' } \\ \text { V } \gamma 10 & : 5^{\prime} \text {-GAA AGG AAT CTG GCA TTC CG-3' } \\ \text { V } \gamma 11 & : 5^{\prime} \text {-GCA GCA TGG GTA AGA CAA GC-3' } \\ \text { J } \gamma 2 S 2 & : 5^{\prime} \text {-GAT TGC TCA GGT GGG AAG AC-3' } \\ \text { JP } & : 5^{\prime} \text {-CCT GTG ACA ACA AGT GTT GT-3' } \\ \text { JP1/2 } & : 5^{\prime} \text {-TTG TTC CGG GAC CAA ATA CC-3' } \\ & : 5^{\prime} \text {-CCA GGT GAA GTT ACT ATG AG-3' }\end{array}$


Mix 2, respectively. The reamplification was done with the same mix as the first cycle.

The presence of the $t(14 ; 18)$ translocation (bcl$2 / \mathrm{J}_{\mathrm{H}}$ rearrangement) was also detected by PCR. The MBR was amplified using oligonucleotide primer $\mathrm{MBR} 3+$, and the $\mathrm{J}_{\mathrm{H}}$ consensus sequence $\mathrm{JH}$ - primer; 29) and the mcr were detected by MC8 primer (30) with the JH- primer.

\section{PCR conditions}

For each initial amplification, either $0.5 \mu \mathrm{g}$ of extracted DNA template or $2.5 \mu \mathrm{L}$ of the tissue lysate, in a total of $50 \mu \mathrm{L}$ PCR reaction mixture, was subjected to 35 cycles of PCR amplifications using AmpliTaq Gold DNA polymerase in a Perkin-Elmer DNA thermal cycler (Perkin-Elmer Corporation, Norwalk, CT) as described elsewhere $(22,31)$. The 35 cycles were performed using conditions adapted for each amplimer set. The PCR cycle consisted of denaturation at $93^{\circ} \mathrm{C}$; annealing at $55^{\circ} \mathrm{C}$ for TcR- $\gamma$ and bcl $-2 / \mathrm{J}_{\mathrm{H}}$, at $54^{\circ} \mathrm{C}$ for $\mathrm{FR} 1 \mathrm{c} / \mathrm{J}_{\mathrm{H}}, \mathrm{FR} 3 \mathrm{a} / \mathrm{J}_{\mathrm{H}}$, and c-raf- 1 , and at $50^{\circ} \mathrm{C}$ for $\beta$-actin and FR2a/ $/ \mathrm{J}_{\mathrm{H}}$ amplimers; followed by extension at $72^{\circ} \mathrm{C}$. The length of each step of amplification cycle was 1 minute. For all PCR amplifications, an initial step of 10 minutes at $93^{\circ} \mathrm{C}$ to denaturate the DNA templates and to activate the AmpliTaq Gold enzyme and a final period of 10 minutes at $72^{\circ} \mathrm{C}$ to complete the reaction were performed. For reamplification of the IgH and TcR- $\gamma$ gene PCR products, $1 \%$ of the first round was used as a template and subjected to another 35-cycle PCR amplification. Then, $20 \mu \mathrm{L}$ of each amplified product was applied to a polyacrylamide $\left(8 \%\right.$ for FR3a $/ \mathrm{J}_{\mathrm{H}}, 6 \%$ for FR2a/ $/ \mathrm{J}_{\mathrm{H}}$ and TcR- $\gamma$, and 4 or $5 \%$ for $\mathrm{FR} 1 \mathrm{c} / \mathrm{J}_{\mathrm{H}}$ ) or to a $2 \%$ agarose (for bcl- $2 / \mathrm{J}_{\mathrm{H}}$, c-raf- 1 , and $\beta$-actin amplification fragments) gel electrophoresis and visualized by staining with ethidium bromide. For TcR- $\gamma$ gene rearrangements, electrophoresis of the first and the second PCR amplification products was systematically performed. In effect, even if the two rounds of PCR amplification improve the sensitivity of the detection, in some rare cases, the band detected after the first PCR can be masked by the increased background generated by the polyclonal T-cell population present in the sample (17).

Amplifications of bcl-2/J $\mathrm{J}_{\mathrm{H}}$ PCR fragments were confirmed by hybridization with an internal oligonucleotide specific for bcl-2-MBR (MBR-P+ probe) or the bcl-2-mcr $(\mathrm{MC12}-\mathrm{F}+$ probe) of the $\mathrm{t}(14 ; 18)$, obtained from the sequences reported by Crescenzi et al. (32) and Ngan et al. (30), at $63^{\circ} \mathrm{C}$ after alkaline transfer of PCR products to Hybond-N+ membranes (Amersham Pharmacia Biotech Europe $\mathrm{GmbH}$, Saclay, France). These probes were end labeled with digoxigenin-11-dUTP $3{ }^{\prime}$ before hybridization, and their fixation was revealed by an alkaline phosphatase-conjugated anti-digoxigenin antibody, followed by BromoChloroIndoyl Phosphate-nitro blue tetrazolium incubation (Roche Diagnostics, Meylan, France). All probe sequences are shown in Table 2.

\section{Sensitivity of PCR}

As reported elsewhere, the sensitivity of the $\operatorname{IgH}$ and TcR- $\gamma$ PCR for the detection of a clonally rearranged cell population is tissue dependent $(24,33$, 34). Indeed, this sensitivity is dependent on the number of polyclonal cells present in the sample, which is coamplified with the clonal cell population if present. Because the number of polyclonal cell differs between tissues, the origin of the tissue examined should be taken into account in the interpretation of the results. In our previous reports, we demonstrated that using the sn-PCR assay for the detection of IgH gene rearrangement, a clonalrearranged B-cell population of approximately $\geq 1 \%$ of total cells is detectable in a background of lymph node-based polyclonal B-cells (22). In the absence of polyclonal cell population, this technique was sufficiently sensitive to produce a detectable band from a single IgH gene-rearranged B-cell (24). The applications of the same conditions of PCR amplifications for TcR- $\gamma$ genes yielded comparable results (22 and data not shown). The sensitivity of IgH and TcR- $\gamma$ PCR gene amplifications for the detection of clonal cell populations in bone marrow samples was intermediate between the abovementioned values. Using $\mathrm{FR} 1 \mathrm{c} / \mathrm{J}_{\mathrm{H}}, \mathrm{FR} 2 \mathrm{a} / \mathrm{J}_{\mathrm{H}}$, and FR3a/ $\mathrm{J}_{\mathrm{H}}$ PCR amplifications, a clonal B-cell population was detectable when it constituted $\geq 0.1 \%$ of the total bone marrow mononuclear cell populations, whereas a clonal T-cell population was detectable when it represented $\geq 0.5 \%$ and $\geq 0.1 \%$ of the total DNA for TcR- $\gamma / \mathrm{mix}-\mathrm{I}$ and TcR- $\gamma / \mathrm{mix}-\mathrm{II}$, respectively. Finally, for the detection of the $t(14 ; 18)$ chromosomal translocation, using the technique reported in this study, we were able to detect $\mathrm{t}(14$; 18)-positive DNA representing $\geq 0.1 \%$ of the total DNA analyzed; in other words, this method detects 50 positive cells (equivalent to $0.5 \mathrm{ng}$ ) diluted in 50,000 cells (equivalent to $0.5 \mu \mathrm{g}$ DNA used for each PCR amplification).

\section{RESULTS}

IgH-Chain and TcR- $\gamma$ Gene Rearrangement Studies of B-Cell and T-Cell Lymphomas

In the group of 183 well-characterized B-cell lymphomas, a clonal IgH gene rearrangement was detected in 144 cases (79\%). Clonal rearrangements of IgH chain genes resulted in one or two predominant amplification products within the expected range of size; in other words, 330 to $350 \mathrm{bp}, 230$ to 
$270 \mathrm{bp}$ (Fig. 1), and 70 to $110 \mathrm{bp}$ for $\mathrm{FR} 1 \mathrm{c} / \mathrm{J}_{\mathrm{H}}$ (5), FR2a/ $J_{H}$, and FR3a/J $J_{H}(2,3)$, respectively. For the study of IgH gene rearrangements in tissue specimens with a relatively small polyclonal B-cell population, such as skin and gastrointestinal samples, we used the multiple sn-PCR experiment (24). Three to five FR1c $/ \mathrm{J}_{\mathrm{H}}, \mathrm{FR} 2 \mathrm{a} / \mathrm{J}_{\mathrm{H}}$, and $\mathrm{FR} 3 \mathrm{a} / \mathrm{J}_{\mathrm{H}}$ PCR amplifications were performed from the same sample, and the demonstration of a band of the same size in all the different PCR runs was considered as indicative of a clonal cell population (Figs. 2 and 3). As shown in Table 1, in precursor B-lymphoblastic leukemia/lymphoma, in chronic lymphocytic leukemia, and in mantle cell lymphoma, cases that usually lack mutations in the $\mathrm{V}_{\mathrm{H}}$ gene segments, the detection rate of clonally rearranged IgH genes was nearly $100 \%$ (10). In this group of lymphomas, the three sets of primers, used in this study for IgH gene rearrangement analysis, were usually all positive, indicating the unmutated status of the $\mathrm{V}_{\mathrm{H}}$ segments in these cases (4). By contrast, in the other B-cell lymphoma types, considered by the presence of mutated $\mathrm{V}_{\mathrm{H}}$ genes to be of GC or post-GC memory B-cell origin (10), a clonal IgH gene rearrangement was detected in only $76 \%$ of cases. As expected, in this latter group of lymphomas, the positivity of each set of primers was much lower because among the 143 cases studied, a clonal IgH gene rearrangement was found in 78 (55\%), 94 (66\%), and $45(31 \%)$ of the cases, using FR1c $/ \mathrm{J}_{\mathrm{H}}, \mathrm{FR} 2 \mathrm{a} / \mathrm{J}_{\mathrm{H}}$, and FR3a/ $\mathrm{J}_{\mathrm{H}}$ primers, respectively. It was of note that using the three sets of primers, the detection rate of clonality reached $76 \%$ (109/143) compared with the highest rate obtained; that is, $66 \%$ using only $\mathrm{FR} 2 \mathrm{a} / \mathrm{J}_{\mathrm{H}}$. However, cases bearing a clonal IgH rearrangement (109 cases) were detected using only $\mathrm{FRlc} / \mathrm{J}_{\mathrm{H}}$ and FR2a/ $\mathrm{J}_{\mathrm{H}}$ primers, and PCR using $\mathrm{FR} 3 \mathrm{a} / \mathrm{J}_{\mathrm{H}}$ did not increase the detection rate of positive cases. By comparison, the detection rate of IgH rearrange-

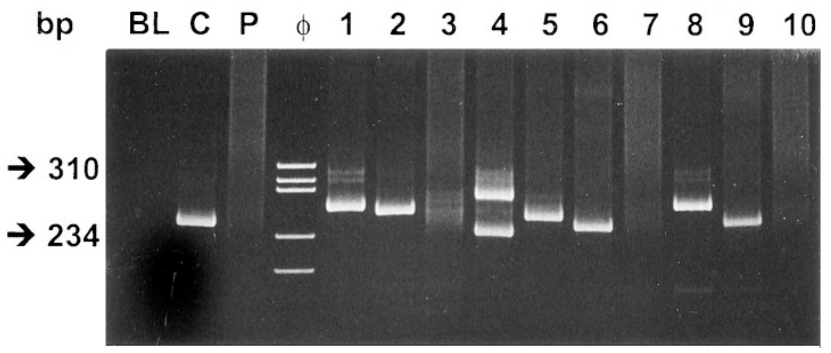

FIGURE 1. Examples of polymerase chain reaction analysis of $\operatorname{IgH}$ chain gene rearrangements using $\mathrm{FR} 2 \mathrm{a} / \mathrm{J}_{\mathrm{H}}$ primers in $10 \mathrm{lymph}$ node specimens (1-10). Reactions were subjected to $6 \%$ polyacrylamide gel electrophoresis and stained with ethidium bromide. Lane $\phi$ : size markers in base pairs (bp). Lane BL (blank): Polymerase chain reaction amplification without DNA template. Lane C: Positive control (B-cell lymphoma). Lane P: Polyclonal control (reactive lymph node). Samples $1,2,4,5,6,8$, and 9 show one or two rearranged bands between 230 and $270 \mathrm{bp}$, indicating the presence of clonally IgH-rearranged cell population in these lymph node specimens. The other samples $(3,7$, and 10) show a polyclonal smear.

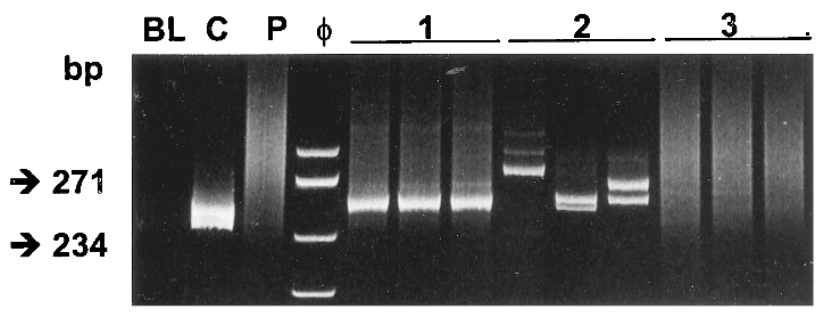

FIGURE 2. Multiple seminested polymerase chain reaction (PCR) analysis of gastric samples from three cases (1-3) of suspected MALT lymphoma using FR2a/J $\mathrm{J}_{\mathrm{H}}$ primers. Reactions were subjected to electrophoresis on a $6 \%$ polyacrylamide gel and stained with ethidium bromide. Lane $\phi$ : the DNA size markers in base pairs (bp). Lane BL (blank): A PCR amplification without DNA template to rule out contamination. Lanes $\mathrm{C}$ and $\mathrm{P}$ are a positive B-cell lymphoma cell line and a polyclonal control (polyclonal lymph node DNA), respectively. In Case 1, the three PCR runs performed from each sample showed the presence of a rearranged band of the same size within the expected range of size (230-270 bp). These findings confirmed the presence of clonal B population in this sample. Cases 2 and 3 show either different rearranged bands in each of the three PCR runs performed from this sample (Case 2) or from polyclonal smear (the three PCR runs; Case 3). These results indicate the reactive nature of the B-cell populations in these two cases.

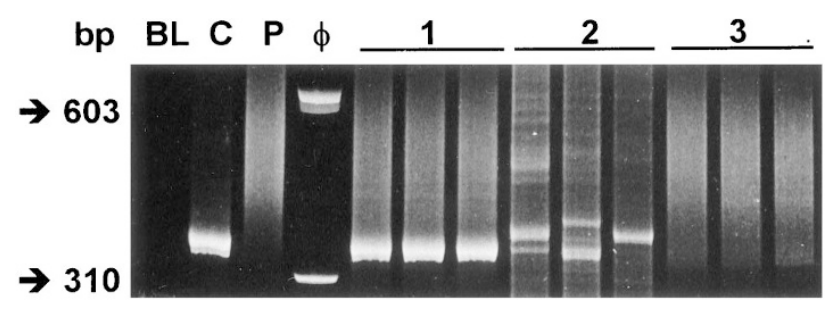

FIGURE 3. Multiple seminested polymerase chain reaction (PCR) analysis of skin samples from three cases of suspected primary cutaneous lymphomas using $\mathrm{FR} 1 \mathrm{c} / \mathrm{J}_{\mathrm{H}}$ primers. Reactions were subjected to electrophoresis on a $4 \%$ polyacrylamide gel and stained with ethidium bromide. Lane $\phi$ : DNA size markers in base pairs (bp). Lane BL (blank): PCR amplification without DNA template to rule out contamination. Lanes $\mathrm{C}$ and $\mathrm{P}$ are a positive B-cell lymphoma cell line and a polyclonal (polyclonal lymph node DNA) control, respectively. In Case 1, PCR shows the presence of one rearranged band of the same size within the expected range of size $(330-350 \mathrm{bp})$ in all the three PCR runs performed from each sample. This finding confirms the presence of a clonal B-cell population in this sample. The final diagnosis was primary cutaneous B-cell lymphoma. Cases 2 and 3 show either different rearranged bands in each of the 3 PCR runs performed from this sample (Case 2) or from polyclonal smear (the three PCR runs; Case 3). These results indicate the reactive nature of the B-cell populations in these two cases. These results were in agreement with the final diagnosis of benign cutaneous lymphoid infiltrates.

ment using FR1c $/ \mathrm{J}_{\mathrm{H}}$ and FR3a $/ \mathrm{J}_{\mathrm{H}}$ or using FR2a $/ \mathrm{J}_{\mathrm{H}}$ and FR3a/ $\mathrm{J}_{\mathrm{H}}$ was $59 \%(84 / 143$ cases) and $67 \%$ (96/ 143 cases), respectively. TcR- $\gamma$ genes were also found to be rearranged in 18 of the 144 cases showing clonally IgH rearranged genes (Table 1). No IgH or TcR- $\gamma$ gene rearrangement was found in the remaining 39 cases $(21 \%)$ of B-cell lymphomas studied.

Of the 90 T-cell lymphomas diagnosed on immunomorphologic criteria, a TcR- $\gamma$ gene rearrangement was detectable in 74 cases $(82 \%$; Table 1$)$. As expected, PCR products for TcR- $\gamma$ chain gene rearrangements were approximately of 230 and $125 \mathrm{bp}$ 
for the Mix 1 (Fig. 4) and Mix 2 primer pairs, respectively (22). The anaplastic large-cell lymphomas showed a lower detection rate of clonality $(19 / 29$ [65.5\%]) in comparison with the other types of T-cell lymphomas (55/61 [90\%]). In 10 of the 74 positive cases, TcR- $\gamma$ gene rearrangement was associated with IgH gene rearrangement (Table 1). As demonstrated in Table 1, the angioimmunoblastic T-cell lymphomas gave a higher rate of rearrangements involving both IgH and TcR- $\gamma(3 / 12 ; 25 \%)$ in comparison with the other T-cell subtypes $(7 / 78$; $9 \%)$. The remaining 16 cases (18\%) investigated showed a polyclonal pattern.

\section{Detection of IgH-Chain and TcR- $\gamma$ Gene Rearrangements in Cases with No Definite Diagnosis after Immunomorphologic Study}

In 85 cases including 49 skin lesions and 36 noncutaneous lymphoid disorders (20 lymph node samples, 9 bone marrow biopsies, and 7 other miscellaneous tissue specimens), no definite diagnosis could be made after histopathologic examination associated with immunohistochemistry (Table 3).

\section{Skin tissue samples}

For the 49 skin tissue samples, the suggested diagnosis after immunomorphological studies was as follows (Table 3).

(1) Primary cutaneous T-cell lymphomas versus nonneoplastic T-cell infiltrate was a question in 37 cases. Gene rearrangement study showed a clonal TcR- $\gamma$ gene rearrangement in 21 cases, a clonal birearranged cell population $([\mathrm{TcR}-\gamma / \mathrm{IgH}]+)$ in 1 case, and a clonal IgH gene rearrangement in another 1 . In the 14 remaining cases, gene rearrangement study yielded polyclonal patterns. Among the 21 TcR- $\gamma$-positive cases, the correlation between immunomorphology, PCR results, and

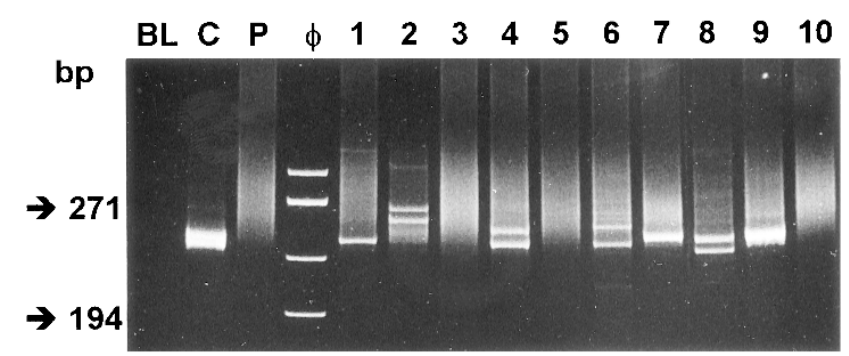

FIGURE 4. Examples of PCR analysis of TcR- $\gamma$ gene rearrangements using TcR- $\gamma /$ Mix 1 PCR amplification in 10 cases of suspected T-cell lymphomas (Lanes 1-10). Lane C: Positive control (T-cell lymphoma). Lane $\phi$ : Size markers. Lane BL (blank): PCR amplification without DNA template. Lane $\mathrm{P}$ is a polyclonal control (reactive lymph node). Tissue Samples 1, 2, 4, and 6 through 9 show the presence of a clonal TcR- $\gamma-$ positive cell population indicated by the presence of one or two bands of approximately $230 \mathrm{bp}$. The other samples (3, 5, and 10) show a polyclonal smear. clinical findings led to the final diagnosis of primary cutaneous T-cell lymphoma in 15 cases, whereas in 4 cases, the lymphoid infiltrate was considered nonneoplastic and related to lymphomatoid papulosis in 3 cases and to pseudolymphoma in 1 case (35). None of these patients developed a lymphoma after 3 to 4 years of follow-up. In the two remaining cases, no definite diagnosis was made. No definite diagnosis was made in the case showing clonally rearranged TcR- $\gamma$ and $\mathrm{IgH}$ genes. In the 14 PCR-negative cases, 9 cases were finally considered to be nonneoplastic lymphoid infiltrates, and one case remained without definite diagnosis, whereas the four remaining cases proved to be cutaneous T-cell lymphoma on the basis of the clinical follow-up, despite the absence of a detectable clonally rearranged lymphoid cell population. The last case with IgH-positive rearrangement was found in a clinical context of psoriasis.

(2) In 11 cases, consisting of a predominant B-cell population, the immunomorphological features raised the question of malignant versus reactive B-cell infiltrate. Gene rearrangement analysis confirmed the clonal nature $(\mathrm{IgH}+)$ of the B-cell population in nine of these cases. In the two remaining cases, PCR demonstrated a polyclonal pattern in one case and a TcR- $\gamma$-positive cell population in the remaining one. The correlation between immunohistological, gene rearrangement analysis-based, and clinical findings allowed a definite diagnosis of primary cutaneous B-cell lymphoma in eight of the nine IgHpositive cases. In the remaining case, no definite diagnosis was made. The one polyclonal case was considered to be benign cutaneous lymphoid infiltrate, and no definite diagnosis was made in the TcR- $\gamma$-positive case.

(3) In one case, the lymphoid Infiltrate was of mixed $\mathrm{B}$ and $\mathrm{T}$ cells, and the question regarded malignant versus reactive infiltrate. Both IgH and TcR- $\gamma$ were rearranged. Clinical presentation and follow-up supported a neoplastic process, and the final diagnosis was a primary CBCL.

Overall, the results of gene rearrangement studies were contributory to the diagnosis in 34 cases (70\%), of which 24 cases were considered to be malignant and 10 cases, benign lymphoid infiltrates. In the 15 (30\%) remaining cases, gene rearrangement analysis was of no help to elucidate the nature of the lesion (i.e., benign versus malignant; Table 3). 
TABLE 3. Diagnostic Value of PCR in Lymphoproliferations with No Definite Diagnosis after Immunomorphologic Studies (85 Cases)

\begin{tabular}{|c|c|c|}
\hline PCR Analysis & No. of Cases & Final Diagnosis \\
\hline \multicolumn{3}{|l|}{ Cutaneous infiltrates (49 cases) } \\
\hline \multicolumn{3}{|c|}{ 1. Cutaneous infiltrates with a predominant population of T-cells (37 cases) } \\
\hline TcR- $\gamma \mathrm{R}$ & 15 & CTCL \\
\hline TcR- $\gamma \mathrm{R}$ & 4 & Non-neoplastic infiltrate \\
\hline TcR- $\gamma \mathrm{R}$ & 2 & No definite diagnosis \\
\hline TcR- $\gamma \mathrm{R}$ and IgH R & 1 & No definite diagnosis \\
\hline Polyclonal pattern & 9 & Reactive infiltrate \\
\hline Polyclonal pattern & 4 & $\begin{array}{l}\text { The clinical follow-up supported the diagnosis } \\
\text { of CTCL }\end{array}$ \\
\hline Polyclonal pattern & 1 & No definite diagnosis \\
\hline IgH R & 1 & Reactive infiltrate \\
\hline \multicolumn{3}{|c|}{ 2. Cutaneous infiltrates with a predominant population of B-cells (11 cases) } \\
\hline IgH R & 8 & CBCL \\
\hline IgH & 1 & No definite diagnosis \\
\hline TcR- $\gamma$ R & 1 & No definite diagnosis \\
\hline Polyclonal pattern & 1 & Reactive infiltrate \\
\hline \multicolumn{3}{|c|}{ 3. Cutaneous infiltrates with a mixture of T- and B-cells } \\
\hline TcR- $\gamma$ and IgH R & 1 & CBCL \\
\hline \multicolumn{3}{|l|}{ Non-cutaneous infiltrates (36 cases) } \\
\hline \multicolumn{3}{|c|}{ 1. Lymphoid infiltrates with a predominant population of B-cells (11 cases) } \\
\hline IgH R & 7 & B-cell lymphoma \\
\hline IgH R and TcR- $\gamma \mathrm{R}$ & 4 & B-cell lymphoma \\
\hline \multicolumn{3}{|c|}{ 2. Lymphoid infiltrates with a predominant population of T-cells (8 cases) } \\
\hline TcR- $\gamma \mathrm{R}$ & 5 & T-cell lymphoma \\
\hline TcR- $\gamma \mathrm{R}$ and IgH R & 3 & T-cell lymphoma \\
\hline \multicolumn{3}{|c|}{ 3. Lymphoid infiltrates with a mixture of T- and B-cells (17 cases) } \\
\hline IgH R & 2 & B-cell lymphoma \\
\hline IgH R & 3 & No definite diagnosis \\
\hline $\mathrm{TcR}-\gamma \mathrm{R}$ & 2 & T-cell lymphoma \\
\hline TcR- $\gamma \mathrm{R}$ & 1 & Reactive infiltrate \\
\hline IgH R and TcR- $\gamma$ R & 1 & B-cell lymphoma \\
\hline Polyclonal pattern & 7 & Reactive infiltrate \\
\hline Polyclonal pattern & 1 & $\begin{array}{l}\text { No definite diagnosis in a patient with } \\
\text { Gougerot-Sjögren syndrome who developed a } \\
\text { B-cell lymphoma } 2 \text { years later }\end{array}$ \\
\hline
\end{tabular}

R, rearranged; CTCL, cutaneous T-cell lymphoma; CBCL, cutaneous B-cell lymphoma.

No definite diagnosis: means that no conclusion could be made taking into account immunomorphological features, PCR results and clinical follow-up.

\section{Noncutaneous lymphoid proliferations}

In the 36 cases of noncutaneous lymphoid proliferations, the diagnosis uncertainties were as follows (Table 3).

(1) in 11 cases, the immunomorphologic feature was suggestive of a B-cell lymphoma. A clonal IgH gene rearrangement was detected in all of these cases, associated with TcR- $\gamma$ gene rearrangement in four of them. The diagnosis of B-cell lymphomas was made and confirmed by the clinical evolution.

(2) In eight cases, the immunomorphologic characteristics of the infiltrate was evocative of a T-cell lymphoma. A clonal TcR- $\gamma$ gene rearrangement was detected in all cases, associated with an IgH gene rearrangement in three of them, and led to a final diagnosis of T-cell lymphoma. The clinical follow-up results were concordant with such a diagnosis.

(3) In the remaining 17 cases, after immunohistological examination, we were unable to decide between a malignant or reactive lymphoid disorder. In nine cases, a clonal gene rearrangement involving $\operatorname{IgH}(n=5)$, TcR- $\gamma$ $(n=3)$, or both IgH and TcR- $\gamma(n=1)$ was detected. Only two of the five cases showing a clonal IgH gene rearrangement proved to be a B-cell lymphoma. In the three cases with TcR- $\gamma$-positive lymphoid cell populations, the correlation between the immunohistological, gene rearrangement, and clinical findings led to the diagnosis of T-cell lymphoma in two cases and of reactive process in the third. In the case with the birearranged (IgH/ TcR- $\gamma$ )-cell population, immunomorphologic features suggested either an Epstein-Barr-associated B-cell lymphoma or an EpsteinBarr-induced reactive florid immunoblastic proliferation (36). The clonal nature of the lymphoid population led to the diagnosis of diffuse large B-cell lymphoma. The clinical presentation and follow-up were in agreement with the latter diagnosis. In eight cases, no detectable rearrangement was found, and the final diagnosis was reactive lymphoid disorders (Table 3). In seven of these cases, the clinical evolution was in agreement with the diagnosis of reactive infiltrates. In the re- 
maining case, the diagnosis remained undetermined between malignant lymphoma and reactive process in a clinical context of Gougerot-Sjögren syndrome. This patient developed a diffuse large B-cell lymphoma 2 years later.

Overall, the results of the gene rearrangement studies were contributive in 31 cases $(86 \%)$, of which 24 corresponded to malignant lymphoid infiltrates and 7, to benign lymphoid infiltrates (Table $3)$.

Taken together, the results of the PCR monoclonality analysis were contributive in 65/85 cases (76\%) in resolving the diagnosis difficulties in these different lymphoid pathologies.

IgH and TcR $\gamma$-Chain Gene Rearrangement

Studies in 167 Cases of Reactive or Nonneoplastic Lymphoid Disorders

167 cases clinically and immunohistologically proven to be reactive lymphoid proliferations were included in this study. In 20 cases (12\%), a clonal rearrangement was detected, involving $\operatorname{IgH}(n=5$; $3 \%)$ or TcR- $\gamma(n=15$; $9 \%)$ genes. The clinical context was extremely variable and included autoimmune diseases, infectious states, neoplastic processes, and various cutaneous lesions.

\section{Detection of Rearranged bcl-2/ $\mathrm{J}_{\mathrm{H}}$ and/or $\operatorname{lgH}$} Gene Chain in FL

Among the 85 cases of FL, 40 cases (47\%) were found to have an amplifiable $t(14 ; 18)$ translocation (MBR: 39 cases; mcr: 1 case). The PCR products were expected to range from approximately 150 to $400 \mathrm{bp}$ for $\mathrm{t}(14 ; 18)$-MBR (29) and from 500 to 1000 $\mathrm{bp}$ for $\mathrm{t}(14 ; 18)$-mcr $(30)$. Rearranged IgH genes were found in $65 / 85(76 \%)$ cases (34 cases $\left[\mathrm{bcl}-2 / \mathrm{J}_{\mathrm{H}}\right]+$ and 31 cases $\left[\mathrm{bcl}-2 / \mathrm{J}_{\mathrm{H}}\right]-$ ). Thus, in FL, the use of IgH and bcl- $2 / \mathrm{J}_{\mathrm{H}}$ gene rearrangement analyses allowed the detection of monoclonality in 71/85 (84\%) of cases. No bcl- $2 / \mathrm{J}_{\mathrm{H}}$ or IgH gene rearrangement was found in 14 cases (16\%). The efficacy of each of the three sets of primers used for IgH gene rearrangement analysis was variable from one set to another. Of the 65 IgH-positive cases, 28 cases (43\%), 18 cases $(28 \%)$, and 19 cases $(29 \%)$ were positive for only one, two, or three of the sets of primers, respectively. As mentioned above, all IgHpositive cases were detected with the association of FR1c $/ \mathrm{J}_{\mathrm{H}}$ and FR2a $/ \mathrm{J}_{\mathrm{H}}$, and the use of the FR3a/ $\mathrm{J}_{\mathrm{H}}$ did not increase the number of positive cases.

\section{DISCUSSION}

In this study, PCR amplification of the IgH gene rearrangement was performed with three sets of primers $(2,3,5,37)$. We demonstrated that $\operatorname{IgH}$ gene rearrangement was detectable in approximately $80 \%$ of B-cell non-Hodgkin's lymphomas. These results are comparable to those reported in series based on a large number of B-cell lymphomas of different categories (11-13). It appears that the addition of the third primer set, FR3a $/ \mathrm{J}_{\mathrm{H}}$, does not increase the number of IgH-positive cases. However, FR3a $/ \mathrm{J}_{\mathrm{H}}$ primers could be of diagnostic value when the immunomorphological study is inconclusive and there is a differential diagnosis between two types of B-cell lymphomas, such as mantle cell lymphoma versus FL. Overall, the positivity of the three sets of primers is suggestive of an unmutated status of the $\mathrm{V}_{\mathrm{H}}$ gene of the lymphoma cells (i.e., pre-GC B-cell origin, such as mantle cell lymphoma), whereas the positivity of $\mathrm{FR} 1 \mathrm{c} / \mathrm{J}_{\mathrm{H}}$ and/or $\mathrm{FR} 2 \mathrm{a} / \mathrm{J}_{\mathrm{H}}$ together with the negativity of $\mathrm{FR} 3 \mathrm{a} / \mathrm{J}_{\mathrm{H}}$ is mainly found in lymphomas of GC (such as FL) and post-GC B-cell origin. In FL, the detection of bcl- $2 / \mathrm{J}_{\mathrm{H}}$ rearrangement is a diagnostic adjunct, but only $50 \%$ were found to be positive with sets of primers detecting MBR and mcr, which is comparable to the results reported in other European series $(37,38)$.

As far as the routine use of PCR methodology is concerned, the results of this study stress the importance of the origin of the tissue sample analyzed. Indeed, the sensitivity of PCR in detecting clonal IgH rearrangement is strongly dependent on the relative number of polyclonal lymphoid cells, which are coamplified with the clonal population if present in the sample $(24,33,34)$. As demonstrated in this study, these polyclonal lymphoid cells can be responsible for a pseudoclonal PCR profile (see Figs. 2 and 3). Therefore, when IgH gene rearrangement study was performed using tissue specimens containing a relatively small number of polyclonal $\mathrm{B}$ cells (i.e., skin and gastrointestinal biopsies), we used a multiple-PCR strategy that involves three to five PCR reactions from the same sample (24). Using this strategy, the demonstration of the same rearranged band in every experiment is highly indicative of the presence of clonal B-cell population in the analyzed sample. Inversely, when the B-cell population is polyclonal, each PCR experiment gives different rearranged bands in size and in sequence (pseudoclonal pattern; 24 and data not shown).

In T-cell lymphomas, a clonal TcR- $\gamma$ gene rearrangement was found in approximately $80 \%$ of cases, which is comparable to the results reported in the literature (16-19). The highest percentage of positive cases was found in cutaneous T-cell lymphomas and peripheral T-cell lymphomas (unspecified) and the lowest, in anaplastic large-cell lymphomas. As reported elsewhere, in the skin, the demonstration of a clonal TcR- $\gamma$ gene rearrange- 
ment was found to be of diagnostic value in distinguishing reactive infiltrates rich in $\mathrm{T}$ cells from cutaneous T-cell lymphomas (39-41). However, TcR- $\gamma$ gene rearrangement is not restricted to T-cell lineage and can occur in various B-cell lymphomas, although rarely in mature neoplastic B-cell proliferations (42-44). Of note is the detection of a clonal IgH gene rearrangement in approximately $10 \%$ of T-cell lymphomas (45-47), which is of the same degree of magnitude as the detection of TcR- $\gamma$ rearrangement in B-cell lymphomas (approximately $5 \%$ of cases; $2,47,48$ ). It is noteworthy that the presence of clonal TcR- $\gamma$ gene rearrangement was mainly found in B-cell lymphoma subtypes, such as follicular, MALT-type, and T-cell-rich B-cell lymphomas, which are known to contain large numbers of $\mathrm{T}$ lymphocytes admixed with neoplastic $\mathrm{B}$ cells. The detection of such a rearrangement may simply reflect the presence of oligoclonal expansion of tumor-infiltrating T-lymphocytes rather than a dual rearrangement involving neoplastic B-cells (49-51). In such circumstances, only single-cell gene rearrangement study of tumor-infiltrating T-lymphocytes in non-Hodgkin's B-cell lymphoma-affected tissues could address this issue (52). Clonal populations of nonneoplastic T-cells have also been described in patients with B-cell chronic lymphocytic leukemia and multiple myeloma (53, 54) and even in healthy elderly humans (55).

In difficult diagnostic situations, PCR results must be combined with clinical presentation and follow-up. In 85 cases, no definite diagnosis could be made after histopathological examination associated with immunohistochemistry. Overall, the results of the gene rearrangement studies were contributive in approximately $75 \%$ and were in agreement with the follow-up (see Table 3). As previously reported, in $12 \%$ of lymphoid infiltrates proved to be clinically and immunohistologically reactive, we found a clonal rearrangement involving IgH (3\% of cases) or TcR- $\gamma(9 \%)$ genes. The majority of patients presented with autoimmune diseases, including Sjögren syndrome, systemic lupus erythematous, and rheumatoid arthritis, which are characterized by polyclonal B-cell activation and autoantibodies (56). Overt B-cell clonal expansion occurs in some cases, suggesting an antigendriven B-cell expansion $(56,57)$. In addition, many examples of clonal T-cell expansion in tumorinfiltrating lymphocytes in patients with tumors and autoimmune diseases have been reported (5860). Furthermore, clonal expansion of $\mathrm{T} / \gamma \delta$ lymphocytes has been reported to occur in granulomatous diseases such as sarcoidosis and tuberculosis, and some of our cases (data not shown) fell in this category $(61,62)$. Conversely, the failure to detect a clonal population in an immunomorphological and clinical context highly sug- gestive of a malignant process (in approximately $10-20 \%$ of malignant lymphoid proliferations) should be interpreted with caution. Among the factors responsible for these negative results are sampling errors or a low number of malignant cells under the threshold of PCR detection at the time of the analysis.

In conclusion, the results of this study further emphasize the value of gene rearrangement study in human lymphoid pathology. The use of the multiple-PCR run approach with the same DNA sample should be used as a complementary tool for the analysis of Ig and TcR gene rearrangements, in particular in biopsy specimens containing a small number of polyclonal lymphocytes. The addition of DNA technology to the immunomorphological and clinical findings increases the likelihood of early diagnosis and appropriate therapy.

Acknowledgments: We would like to thank Professor S.M. Chittal (Memorial University, St. John's, Newfoundland, Canada) for critical reading of the manuscript. We thank Dr. N.L. Berinstein (Regional Cancer Center, Toronto, Ontario, Canada) for kindly providing OCI LY8 lymphoma cell line. We are also grateful to the staff of the Pathological Anatomy laboratory, in particular to Michel March, Jeanine Boyes, and Reine Claude Zenou for their excellent technical assistance.

\section{REFERENCES}

1. Segal GH. Assessment of B-cell clonality by the polymerase chain reaction: a pragmatic overview. Adv Anat Pathol 1996; 3:195-203.

2. Trainor KJ, Brisco MJ, Wan JH, Neoh S, Grist S, Morley AA. Gene rearrangement in B- and T-lymphoproliferative disease detected by the polymerase chain reaction. Blood 1991; 78:192-6.

3. Ramasamy I, Brisco M, Morley AA. Improved PCR method for detecting monoclonal immunoglobulin heavy chain rearrangement in B cell neoplasms. J Clin Pathol 1992;45: $770-5$.

4. Deane M, McCarthy KP, Wiedemann LM, Norton JD. An improved method for the detection of B-lymphoid clonality by polymerase chain reaction. Leukemia 1991;5:726-30.

5. Aubin J, Davi F, Nguyen-Salomon F, Leboeuf D, Debert C, Taher M, et al. Description of a novel FR1 IgH PCR strategy and its comparison with three other strategies of clonality in B cell malignancies. Leukemia 1995;9:471-9.

6. Ilyas M, Jalal H, Linton C, Rooney N. The use of the polymerase chain reaction in the diagnosis of B-cell lymphomas from formalin-fixed paraffin-embedded tissue. Histopathology 1995;26:333-8.

7. Inghirami G, Szabolcs M, Yee HT, Corradini P, Cesarman E, Knowles DM. Detection of immunoglobulin gene rearrangement of B cell non-Hodgkin's lymphomas and leukemias in fresh, unfixed and formalin-fixed, paraffin-embedded tissue by polymerase chain reaction. Lab Invest 1993;68:746-57.

8. Segal GH, Jorgensen T, Masih AS, Braylan RC. Optimal primer selection for clonality assessment by polymerase chain reaction analysis: I. Low grade B-cell lymphoprolifera- 
tive disorders of nonfollicular center cell type. Hum Pathol 1994;25:1269-75.

9. Fais F, Ghiotto F, Hashimoto S, Sellars B, Valetto A, Allen SL, et al. Chronic lymphocytic leukemia B cells express restricted sets of mutated and unmutated antigen receptors. J Clin Invest 1998;102:1515-25.

10. Küppers R, Klein U, Hansmann ML, Rajewsky K. Cellular origin of human B-cell lymphomas. N Engl J Med 1999;34: 1520-9.

11. Lombardo JF, Hwang TS, Maiese RL, Millson A, Segal GH. Optimal primer selection for clonality assessment by polymerase chain reaction analysis. III: Intermediate and highgrade B-cell neoplasms. Hum Pathol 1996;27:373-80.

12. Lehman CM, Sarago C, Nasim S, Comerford J, Karcher DS, Garrett CT. Comparison of PCR with Southern hybridization for the routine detection of immunoglobulin heavy chain gene rearrangements. Am J Clin Pathol 1995;103:171-6.

13. Segal GH, Jorgensen T, Scott M, Braylan RC. Optimal primer selection for clonality assessment by polymerase chain reaction analysis: II. Follicular lymphomas. Hum Pathol 1994; 25:1276-82.

14. Forster A, Huck S, Ghanem N, Lefranc MP, Rabbitts TH. New subgroups in the human $\mathrm{T}$ cell rearranging $\mathrm{V} \gamma$ gene locus. EMBO J 1987;6:1945-50.

15. Takeshita S, Toda M, Yamagishi H. Excision of the $T$ cell receptor gene support a progressive rearrangement model of the $\alpha / \delta$ locus. EMBO J 1989;8:3261-70.

16. Lorenzen J, Jux G, Zhao-Höhn M, Klöckner A, Fischer R, Hansmann ML. Detection of T-cell clonality in paraffinembedded tissues. Diagn Mol Pathol 1994;3:93-9.

17. McCarthy KP, Sloane JP, Kabarowski J, Matutes E, Wiedemann LM. A simplified method of detection of clonal rearrangements of the T-cell receptor- $\gamma$ chain gene. Diagn Mol Pathol 1992;1:173-9.

18. Slack DN, McCarthy KP, Wiedemann LM, Sloane JP. Evaluation of the sensitivity, specificity and reproducibility of an optimized method for detecting clonal rearrangements of immunoglobulin and $\mathrm{T}$-cell receptor genes in formalinembedded sections. Diagn Mol Pathol 1993;2:223-32.

19. Benhattar J, Delacretaz F, Martin P, Chaubert P, Costa J. Improved polymerase chain reaction detection of clonal T-cell lymphoid neoplasms. Diagn Mol Pathol 1995;4:10812.

20. Harris NL, Jaffe ES, Stein H, Banks PM, Chan JK, Cleary ML, et al. A revised European-American classification of lymphoid neoplasms: a proposal from the International Lymphoma Study Group. Blood 1994;84:1361-92.

21. Delsol G, Chittal S, Brousset P, Caverivière P, Roda D, Mazerolles $\mathrm{C}$, et al. Immunohistochemical demonstration of leucocyte differentiation antigens on paraffin sections using a modified AMeX (ModAMeX) method. Histopathology 1989; 15:461-71.

22. Al Saati T, Galoin S, Gravel S, Lamant L, Roda D, Chittal S, et $a l$. IgH and TcR- $\gamma$ gene rearrangements in Hodgkin's disease by PCR demonstrate lack of correlation between genotype, phenotype and Epstein-Barr virus status. J Pathol 1997;181: 387-93.

23. Berinstein NL, Jamal HH, Kuzniar B, Klock RJ, Reis MD. Sensitive and reproducible detection of occult disease in patients with follicular lymphoma by PCR amplification of $\mathrm{t}(14 ; 18)$ both pre- and post-treatment. Leukemia 1993;7: $113-9$.

24. Galoin S, Daste G, Apoil PA, Chollet F, Roda D, Blancher A, et al. Polymerase chain reaction on cerebrospinal fluid cells in the detection of leptomeningeal involvement by B-cell lymphoma and leukemia: a novel strategy and its implications. Br J Haematol 1997;99:122-30.
25. Bonner TI, Kerby SB, Sutrave P, Gunnel MA, Mark G, Rapp UR. Structure and biological activity of human homologs of the raf/mil oncogene. Mol Cell Biol 1985;5:1400-7.

26. Ziegler BL, Lamping C, Thoma S, Thomas CA. Single-cell cDNA-PCR: removal of contaminating genomic DNA from total RNA using immobilized DNase I. Biotechniques 1992; 13:726-9.

27. Kwok S, Higuchi R. Avoiding false positives with PCR. Nature 1989;339:237-8.

28. Macintyre EA, d'Auriol L, Duparc N, Leverger G, Galibert F, Sigaux F. Use of oligonucleotide probes directed against $\mathrm{T}$ cell antigen receptor gamma delta variable-(diversity)joining junctional sequences as a general method for detecting minimal residual disease in acute lymphoblastic leukemias. J Clin Invest 1990;86:2125-35.

29. Soubeyran P, Cabanillas F, Lee MS. Analysis of the expression of the hybrid gene bcl-2/IgH in follicular lymphomas. Blood 1993;81:122-7.

30. Ngan BY, Nourse J, Cleary M. Detection of chromosomal translocation $\mathrm{t}(14 ; 18)$ within the minor cluster region of bcl-2 by polymerase chain reaction and direct genomic sequencing of the enzymatically amplified DNA in follicular lymphomas. Blood 1989;73:1759-62.

31. Galoin S, Al Saati T, Schlaifer D, Huynh A, Attal M, Delsol G. Oligonucleotide clonospecific probe directed against the junctional sequence of $t(14 ; 18)$ : a new tool for the assessment of minimal residual disease in follicular lymphomas. Br J Haematol 1996;94:676-84.

32. Crescenzi M, Seto M, Herzig GP, Weiss PD, Griffith RC, Korsmeyer SJ. Thermostable DNA polymerase chain amplification of $\mathrm{t}(14 ; 18)$ chromosome breakpoints and detection of minimal residual disease. Proc Natl Acad Sci U S A 1988; 85:4869-73.

33. Segal GH, Hussey CE, Wittwer CT. PCR for T-cell rearrangements. Diagn Mol Pathol 1996;5:297-8.

34. Rockman SP. Determination of clonality in patients who present with diagnosis dilemmas: a laboratory experience and review of the literature. Leukemia 1997;11:852-62.

35. Diamandidou E, Cohen PR, Kurzrock R. Mycosis fungoides and Sezary syndrome. Blood 1996;88:2385-409.

36. Segal GH, Kjeldsberg CR, Smith GP, Perkins SL. CD30 antigen expression in florid immunoblastic proliferations. A clinicopathologic study of 14 cases. Am J Clin Pathol 1994; 102:292-8.

37. Al Saati T, Galoin S, Roda D, Huynh A, Attal M, Delsol G. [Detection of residual disease in follicular lymphomas using the PCR technique: importance of clono-specific probes.] Bull Cancer 1998;85:847-54.

38. Segel MJ, Paltiel O, Zimran A, Gottschalk-Sabag S, Schibi G, Krichevski S, et al. Geographic variance in the frequency of the $t(14 ; 18)$ in follicular lymphoma: an Israeli series compared to the world literature. Blood Cells Mol Dis 1998;24: $62-72$.

39. Theodorou I, Delfau-Larue MH, Bigorgne C, Lahet C, Cochet $\mathrm{G}$, Bagot M, et al. Cutaneous T-cell infiltrates: analysis of $\mathrm{T}$-cell receptor $\gamma$ gene rearrangement by polymerase chain reaction and denaturing gradient electrophoresis. Blood 1995;86:305-10.

40. Bachelez H, Bioul L, Flageul B, Baccard M, MoulonguetMichau I, Verola O, et al. Detection of clonal T-cell receptor gamma gene rearrangements with the use of the polymerase chain reaction in cutaneous lesions of mycosis fungoides and Sezary syndrome. Arch Dermatol 1995;131:1027-31.

41. Bakels V, van Oostveen JW, van der Putte SC, Meijer CJ, Willemze R. Immunophenotypic and gene rearrangement analysis provide additional criteria to differentiate between cutaneous and pseudo-T-cell lymphomas. Am J Pathol 1997; 150:1941-9. 
42. Subar M, Pelicci P, Neri A, Allavena P, Littman DR, Knowles II DM, et al. Pattern of $\mathrm{T}$ cell receptor gamma gene rearrangement and expression in $\mathrm{B}$ and $\mathrm{T}$ lymphoid malignancies. Leukemia 1988;2:19-26.

43. Asou N, Matsuoka M, Hattori T, Kawano F, Maeda S, Shimada $\mathrm{K}$, et al. $\mathrm{T}$ cell $\gamma$ gene rearrangement in hematologic neoplasms. Blood 1987;69:968-70.

44. Chen Z, Le Paslier D, Dausset J, Degos L, Flandrin G, Cohen $\mathrm{D}$, et al. Human $\mathrm{T}$ cell $\gamma$ genes are frequently rearranged in B-lineage acute lymphoblastic leukemias but not in chronic B cell proliferations. J Exp Med 1987;165:1000-15.

45. Pelicci PG, Knowles II DM, Dalla Favera R. Lymphoid tumors displaying rearrangements of both immunoglobulin and $\mathrm{T}$ cell receptor genes. J Exp Med 1985;162:1015-24.

46. O'Connor NTJ. Genotypic analysis of lymph node biopsies. J Pathol 1987;151:185-90.

47. Diss TC, Watts M, Pan LX, Burke M, Linch D, Isaacson PG. The polymerase chain reaction in the demonstration of monoclonality in T cell lymphomas. J Clin Pathol 1995;48: 1045-50.

48. Tesch H, May P, Krueger GR, Fischer R, Diehl V. Analysis of immunoglobulin, $\mathrm{T}$ cell receptor and bcr rearrangements in human malignant lymphoma and Hodgkin's disease. Oncology 1990;47:215-23.

49. Pitera R, Pitera JE, Mufti GJ, Slisbury R. Genotype study of non-Hodgkin's lymphoma. Pathol Res Pract 1995;191:44455.

50. Yumoto N, Araki A, Sumida T, Saito T, Tanigushi M, Mikata A. Restricted $\mathrm{V} \beta$ gene usage of tumour-infiltrating $\mathrm{T}$ lymphocytes in primary gastric B-cell lymphoma. Virchows Arch 1995;426:11-8.

51. Oshima K, Masuda Y, Kikuchi M, Sumiyoshi Y, Kobari S, Yoneda S, et al. Monoclonal B cells and restricted oligoclonal $\mathrm{T}$ cells in T-cell-rich B-cell lymphoma. Pathol Res Pract 1994;190:15-24.

52. Roers A, Montesinos-Rongen M, Hansmann ML, Rajewsky K, Kuppers R. Amplification of TCR $\beta$ gene rearrangements from micromanipulated single cells: T cells rosetting around Hodgkin and Reed-Sternberg cells in Hodgkin's disease are polyclonal. Eur J Immunol 1998;28:2424-31.
53. Wen T, Mellstedt H, Jondal M. Presence of clonal T cell populations in chronic B lymphocytic leukemia and smoldering myeloma. J Exp Med 1990;171:659-66.

54. Moss P, Gillespie G, Frodsham P, Bell J, Reyburn H. Clonal populations of CD4 + and CD8 $+\mathrm{T}$ cells in patients with multiple myeloma and paraproteinemia. Blood 1996;87: 3297-306.

55. Posnett DN, Sinha R, Kabak S, Russo C. Clonal populations of T cells in normal elderly humans: the T cell equivalent to "benign monoclonal gammapathy." J Exp Med 1994;179: 609-18.

56. Ferraccioli GF, De Vita S, Casatta L, Damato R, Pegoraro I, Bartoli E. Autoimmune connective tissue disease, chronic polyarthritides and B cell expansion; risks and perspectives with immunosuppressive drugs. Clin Exp Rheumatol 1996; 14:S71-80.

57. Frizzera G. Immunosuppression, autoimmunity, and lymphoproliferative disorders. Hum Pathol 1994;25:627-9.

58. Ferradini L, Mackensen A, Genevée C, Bosq J, Duvillard P, Avril MF, et al. Analysis of T-cell receptor variability in tumor-infiltrating lymphocytes from a human regressive melanoma. Evidence for in situ T cell clonal expansion. J Clin Invest 1993;91:1183-90.

59. Even J, Lim A, Puisieux I, Ferradini L, Dietrich PY, Toubert A, et al. T-cell repertoires in healthy and diseased human tissues analysed by T-cell receptor beta-chain CDR3 size determination: evidence for oligoclonal expansions in tumours and inflammatory diseases. Res Immunol 1995;146:65-80.

60. Masuko-Hongo K, Kato T, Suzuki S, Sekine T, Kurokawa M, Ueda S, et al. Frequent clonal expansion of peripheral T cells in patients with autoimmune diseases: a novel detecting system possibly applicable to laboratory examination. J Clin Lab Anal 1998;12:162-7.

61. Tamura N, Holroyd KJ, Banks T, Kirby M, Okayama H, Crystal RG. Diversity in junctional sequences associated with the common human $\mathrm{V} \gamma 9$ and $\mathrm{V} \delta 2$ gene segments in normal blood and lung compared with the limited diversity in a granulomatous disease. J Exp Med 1990;172:169-81.

62. Forrester JM, Newman LS, Wang Y, King TE Jr, Kotzin BL. Clonal expansion of lung V $\delta 1+\mathrm{T}$ cells in pulmonary sarcoidosis. J Clin Invest 1993;91:292-300.

\section{Book Review}

\section{Ward JM, Mahler JF, Maronpot RR, Sundberg JP, editors: Pathology of Genetically Engi- neered Mice, 394 pp, Ames, IA, lowa State University Press, 2000 (\$174.95).}

This book grew out of a symposium sponsored by the National Institutes of Health in 1999. The editors (three from NIH and one from The Jackson Laboratory) and the publishers deserve to be congratulated for presenting it to us so fast.

The printers cannot keep pace with the progress of science, and thus it is self evident that many data published here have been superseded by newer developments. Nevertheless, this book is an important cornerstone providing a baseline for future endeavors of this kind. Although it is not comprehensive, and accordingly does not cover all the existing mouse models of human diseases, it still contains a wealth of data. Its illustrations are well chosen, reproduced as high-quality color photographs. The text is succinct but informative and profusely referenced. A basic knowledge of pathology is needed for a good understanding of the pictures, but even those who do not use microscopes on a daily basis will profit from studying the material covered in this book.

This monograph is highly recommended to experimental pathologists dealing with biologically engineered mice, but it will be welcomed by many other scientists in academia and industry as well.

Ivan Damjanov

University of Kansas School of Medicine Kansas City, Kansas 